\title{
GROWTH OF CRUSTOSE LICHENS: A REVIEW
}

\author{
Richard Armstrong ${ }^{1}$ and Tom Bradwell ${ }^{2}$ \\ ${ }^{1}$ Vision Sciences, Aston University, Birmingham, UK \\ ${ }^{2}$ British Geological Survey, West Mains Road, Edinburgh, UK
}

Armstrong, R.A. and Bradwell, T., хxхx: Growth of crustose lichens: a review. Geogr. Ann., $92 A(X): x x-x x$.

\begin{abstract}
Crustose species are the slowest growing of all lichens. Their slow growth and longevity, especially of the yellow-green Rhizocarpon group, has made them important for surface-exposure dating (lichenometry). This review considers various aspects of the growth of crustose lichens revealed by direct measurement including: 1) early growth and development, 2) radial growth rates (RGR, $\left.\mathrm{mm} \mathrm{yr}^{-1}\right)$, 3) the growth rate-size curve, and 4) the influence of environmental factors. Many crustose species comprise discrete areolae that contain the algal partner growing on the surface of a non-lichenised fungal hypothallus. Recent data suggest that 'primary' areolae may develop from free-living algal cells on the substratum while 'secondary' areolae develop from zoospores produced within the thallus. In more extreme environments, the RGR of crustose species may be exceptionally slow but considerably faster rates of growth have been recorded under more favourable conditions. The growth curves of crustose lichens with a marginal hypothallus may differ from the 'asymptotic' type of curve recorded in foliose and placodioid species; the latter are characterized by a phase of increasing RGR to a maximum and may be followed by a phase of decreasing growth. The decline in RGR in larger thalli may be attributable to a reduction in the efficiency of translocation of carbohydrate to the thallus margin or to an increased allocation of carbon to support mature 'reproductive' areolae. Crustose species have a low RGR accompanied by a low demand for nutrients and an increased allocation of carbon for stress resistance; therefore enabling colonization of more extreme environments.
\end{abstract}

Key words: Radial growth rate, Thallus development, Growth curve, Lichenometry 


\section{Introduction}

Of the three morphological groups of lichens - fruticose, foliose, and crustose - least is known about the growth of the crustose species. Crustose lichens are intimately associated with the substratum and usually cannot be easily separated from it. The most extreme example of the crustose life style is the endolithic type in which the upper cortex is absent and the algae and medullary hyphae are scattered within the surface layers of the rock (Friedmann 1982; Matthews and Owen 2008). Most crustose lichens, however, have a distinct upper cortex, an algal layer, and a medulla. The margin of some crustose lichens may not be sharply demarcated but many species, exemplified by those of the genus Rhizocarpon, are delimited by a nonlichenised hypothallus (Fig. 1). Moreover, the conspicuous white border seen in many species of Pertusaria and Catillaria may also be a non-lichenised hypothallus. Some crustose species have a 'crustose' centre and lobed margins and are termed 'placodioid' species (Hawksworth and Hill 1984).

Crustose lichens often grow at substantially lower radial growth rates (RGR) than foliose species. For example, the marginal hypothallus of the common species Rhizocarpon geographicum (L.) DC. grows especially slowly, with annual RGR from 0.006 to $1 \mathrm{~mm} \mathrm{yr}^{-1}$ (Hale 1967; Armstrong 1983; Innes 1985; Matthews 1994; Bradwell and Armstrong 2007; Benedict 2008). The slow RGR of many crustose species combined with the difficulties of growing such lichens under controlled conditions for long periods in growth cabinets has made it especially difficult to study their growth. Hence, relatively little is known about the nature and processes of growth, the range of growth rates shown by most species, on the relationship between growth and thallus size (the growth rate-size curve), or on the influence of environmental factors on growth. This lack of fundamental knowledge is of particular concern given their widespread use in lichenometry - a widely practiced surfacedating technique.

The slow growth and longevity of crustose species has made them especially valuable to earth scientists and archaeologists wishing to estimate the exposure age of stone surfaces (see reviews by Locke et al. 1979; Matthews 1994; Innes 1985; Benedict 
2009). There are two main techniques involved in lichenometry. First, direct lichenometry involves the construction of lichen growth curves from direct measurements of lichen growth. Second, indirect lichenometry involves constructing age-size (dating) curves from the size of lichens on surfaces of known age. The most useful crustose lichens in direct and indirect lichenometry are members of the yellowgreen Rhizocarpon group. In relatively dry regions, where growth is very slow and thalli are often assumed to grow at uniform rates for many centuries, the temporal range of lichenometric dating may exceed 9,000 years (Miller and Andrews 1972). When age-size curves of Rhizocarpon species have been derived indirectly from surfaces of known age, various growth phases have been suggested including establishment, juvenile, maturation, and senescent phases; the duration of the various phases having an important influence on the accuracy of the dating method (Porter 1981). Most lichenometric studies, however, suggest an initial 'lag' phase (representing colonization time) leading to a phase of accelerating growth up to a maximum that is then followed by a phase of declining growth; large thalli growing at a slower more constant rate (Beschel 1961; Mottershead and White 1972; Miller 1973; Innes 1988; Bradwell and Armstrong 2007). However, the radial growth rates (RGR) of Rhizocarpon species determined by direct measurement and averaged over several years may also provide close estimates of lichen age and therefore a 'crosscheck' on surface age (McCarthy 2003).

This review considers various aspects of the growth of crustose lichens that have been studied by direct measurement. First, the nature and processes of early growth and development of crustose lichens is described and the RGR of various species from a range of habitats and locations is reviewed. Second, evidence from direct growth studies on the shape of the growth rate-size curve is discussed. Third, the influence of environmental factors on growth is reviewed. Fourth, the implications of growth studies for direct lichenometry are discussed.

\section{Early growth and development}

Much of the experimental work on the early growth of crustose lichens has been carried out on those species which possess a marginal hypothallus. In such species, the thallus usually comprises areolae containing the algal partner, located on a non- 
lichenised fungal hypothallus - the hypothallus extending beyond the areolae to form a marginal ring normally 1-3 mm in width (Armstrong and Bradwell 2001) (Fig. 2). Four processes may be involved in the development of a mature thallus - the formation of 'primary' areolae, growth and division of areolae, the confluence of primary areolae, and the fusion of individual thalli to form larger individuals (Asta and Letrouit-Galinou 1995). The development of primary areolae and the formation of the hypothallus were studied in Rhizocarpon lecanorinum (Flörke ex Körb) Anders by Clayden (1998). When ascospores of $R$. lecanorinum germinate, the hyphae remain very short and do not initially form a hypothallus. A compact soredium-like granule develops, which associates with a compatible species of the green alga Trebouxia. Free-living Trebouxia cells are often the first to colonise a bare substratum and such cells can be detected before any lichen colony has become established (Mukhtar et al. 1994). Thallus differentiation occurs, accompanied by the deposition of rhizocarpic acid within the incipient cortical layer in the apical part of the granule, resulting in the formation of a typical areola.

The radiating hypothallus is initiated by growth from the basal margin of the areolae. In a mature $R$. geographicum thallus, removal of the marginal hypothallus by scraping away tissue with a scalpel, results in regeneration of the hypothallus but by a different mechanism (Armstrong and Smith 1987). First, the margin of the areolae retreats, exposing underlying fungal tissue, and then new hyphal growth occurs to reestablish the marginal hypothallus. After the primary areolae develop, further areolae are continuously formed on the marginal hypothallus, possibly as a result of the overgrowth by the hypothallus of free-living algal cells located on the substratum (Clayden 1998) (Fig. 3). Rhizomorphs of the squamulose lichen Aspicilia crespiana V.J. Rico can capture algal cells thus giving rise to new squamules, a process which may be analogous to that in Rhizocarpon (Sanders and Rico 1992). However, the mechanism of formation of the 'secondary' areolae is controversial. For example, Nienberg (1926) observed in Pertusaria, a genus with a similar growth form to Rhizocarpon, that algal cells from the areolae were 'pushed' into the growing area. Hence, the thallus a few millimetres from the edge was composed of radially elongated hyphae and a few migrating cells could be pushed forwards by these specialised hyphae. In addition, Slocum et al. (1980) observed that Trebouxia, a common algal partner in the yellow-green Rhizocarpon species, could form zoospores 
within the areolae that could 'swim' to colonise the hypothallus. The development of new areolae on the marginal hypothallus after complete or partial removal of the central areolae was studied by Armstrong and Smith (1987). They found that new areolae developed slowly and at a similar rate whether or not the central areolae were completely removed or whether a $2 \mathrm{~mm}$ or $5 \mathrm{~mm}$ 'moat' separated the hypothallus from the areolae. It was concluded that areolae at the margin may develop from freeliving algal cells 'trapped' by the hypothallus, whereas areolae within the centre of the thallus may develop from zoospores originating within existing areolae.

As crustose lichens grow, individual thalli may fuse together to form much larger individuals such that the individuality of the original thalli is lost. The consequence of this phenomenon is that thalli much larger than expected, based on their RGR, may be formed. In addition, thalli of the same and of different species may fuse to form lichen 'mosaics' - a feature of many saxicolous and corticolous lichen communities (Pentecost, 1981). Some crustose lichen thalli may increase dramatically in thickness as they age Ochrolechia tartarea (L.) Massal., for example, may form thalli up to 10 mm thick, the rapidly thickening thallus blistering as it grows, with dead algal cells accumulating in the cortex beneath the living algal zone (Hill 1981).

\section{Growth rates of crustose lichens}

After initial development, the thallus grows to maturity by radial extension of the perimeter. One of the first authors to systematically compare crustose lichen growth rates of different species was Hale (1967), who reported a range of RGR measurements for species of the genera Diploschistes, Lecanora, Lecidea, Rhizocarpon, and Rinodina of between 0.44 and $3.0 \mathrm{~mm} \mathrm{yr}^{-1}$. A selection of the published RGR of crustose species from various habitats and locations is shown in Table 1.

The slowest growth rates have been recorded in dry, continental Arctic and Alpine environments. Of these, possibly the slowest RGR yet measured for a crustose lichen is by Benedict (2008) in a study over 16 years of Rhizocarpon superficiale (Schaer.) Vain. from the Front Range in Colorado where an overall average RGR of $0.006 \mathrm{~mm}$ $\mathrm{yr}^{-1}$ was recorded. Most studies of crustose lichens in these environments have 
confirmed the slow RGR. Hence, in a study in the Cascade Mountains of Washington State, USA, an average RGR of $0.1 \mathrm{~mm} \mathrm{yr}^{-1}$ was obtained for thalli of $R$. geographicum (Armstrong 2005a) while Beschel (1958, 1961) in West Greenland reported RGR of $0.05-0.01 \mathrm{~mm} \mathrm{yr}^{-1}$. Hooker (1980a) studied 63 thalli of $R$. geographicum in the south Orkney Islands and found no measurable growth over a period of three years. Small amounts of growth were recorded, however, during a subsequent three-year period of approximately $0.1 \mathrm{~mm} \mathrm{yr}^{-1}$. Somewhat higher RGR were recorded by Rogerson et al. (1986) in northern Labrador $\left(0.17 \mathrm{~mm} \mathrm{yr}^{-1}\right)$ and by Haworth et al. (1986) in the central Brooks Range, Alaska (0 - $0.18 \mathrm{~mm} \mathrm{yr}^{-1}$ ).

Significantly higher growth rates have been recorded from the maritime regions of the Antarctic. On Livingston Island, for example, an RGR of $0.25 \mathrm{~mm} \mathrm{yr}^{-1}$ has been recorded (Sancho and Pintado 2004). Furthermore, on Signy Island an increase in area of 15 - 32\% per year has been recorded in nitrogenous environments especially in species of the genera Acarospora, Buellia, and Caloplaca (Smith 1995). Hence, exceptionally large thalli in the maritime Antarctic may actually be much younger than previously supposed.

In more temperate environments, studies have reported significantly higher RGR for crustose lichens. McCarthy (1997, 2003), for example reports a RGR for Aspicilia candida (Anzi) Hue. (by lichenometry) in the Canadian Rocky Mountains and $R$. geographicum (by direct measurement) in British Columbia of $0.9 \mathrm{~mm} \mathrm{yr}^{-1}$ and 0.26 $0.42 \mathrm{~mm} \mathrm{yr}^{-1}$ respectively. Higher rates of growth have also been reported for $R$. geographicum from Mount Monadnock, New Hampshire $\left(0.4 \mathrm{~mm} \mathrm{yr}^{-1}\right.$ ) (Hausman 1948), southern Norway (0.18 - $\left.0.44 \mathrm{~mm} \mathrm{yr}^{-1}\right)$ (Trenbirth and Matthews, this volume) and from a glacier in Switzerland (maximum $0.5 \mathrm{~mm} \mathrm{yr}^{-1}$ ) (Proctor 1983), all of these studies by direct measurement.

The highest reported RGRs for crustose species have been found in Europe and especially in the UK. Hence, Winchester and Chaujar (2002) studied the growth of $R$. geographicum spp. prospectans on gravestones in north Wales and estimated RGR to be $0.74 \mathrm{~mm} \mathrm{yr}^{-1}$. Similarly, Sowter (1950) measured the RGR of various crustose lichens in Leicestershire and Rutland and found rates between 1.1 and $2.0 \mathrm{~mm} \mathrm{yr}^{-1}$. Comparable results have been reported by the studies of Rydzak (1956) in Poland, 
Hawksworth and Chater (1979), and Armstrong (2005b) both of the latter studies in the UK.

The growth rate-size curves of crustose lichens

Because of the importance of certain crustose species in lichenometry, there has been considerable interest in the shape of the lichen growth rate-size curve - an expression of the changes in RGR that may occur during the life of a thallus. Studies carried out by direct measurement and by the application of indirect lichenometry have both contributed to this debate, but this section focuses on those studies that have made direct measurements.

Because of the very slow growth rates and consequent longevity of crustose lichens it has not been possible to measure the growth of any single individual throughout its life even in relatively favourable environments. Consequently, studies of the growth curve have been carried out using a 'cross-sectional' method, i.e., by studying individuals of different size and assuming a direct relationship between thallus size and age. This type of study has three main limitations. First, there is no guarantee that the growth curve derived from a population of thalli of different size actually reflects the growth of any single individual throughout its life. Second, variations in RGR between thalli of similar size - due in part to microenvironmental fluctuations and which are considerable in foliose species (Armstrong and Smith 1992) obscure changes that are attributable to size so that only major changes in growth are likely to be observed. Third, these studies all negate the potential long-term (>decadal) effect of climate on growth rate and assume 'average' climatic conditions over the lifespan of the thallus.

A limited number of studies have attempted to determine the growth curve of crustose lichens using cross-sectional studies. In most studies, however, the variability in RGR combined with slow growth rates and small sample sizes has made it difficult to establish the different growth phases with any certainty (Proctor 1983; Haworth et al. 1986; Matthews 1994; McCarthy 2003; Armstrong 2005a). Furthermore, a major objective of this research has been to model the growth curve of crustose lichens as has been accomplished successfully for foliose species (Aplin and Hill 1979). In 
foliose lichens, RGR increases in smaller diameter thalli becoming linear or asymptotic in larger individuals. There is no evidence for a declining growth phase in foliose lichens even when the centre of the thallus degenerates and fragments (Armstrong 1974; Aplin and Hill 1979; Armstrong and Smith 1996, 1997). This type of growth curve can be explained by a mathematical model developed by Aplin and Hill (1979), which is based on the rates of carbohydrate production within the thallus and the degree of translocation of carbohydrate between individual lobes and from edge to centre.

Early studies of the growth curves of crustose lichens often assumed that they mirrored the relationship between RGR and thallus size established for foliose lichens (Aplin and Hill, 1979). Hence, Proctor (1977) studied the growth curve of the placodioid species Buellia (Diploicia) canescens (Dicks.) De Not. It was assumed that RGR was proportional to an area of thallus in an annulus of constant width within the growing margin and that the shape of the growth curve was essentially asymptotic (i.e., RGR increases rapidly and then 'flattens off'). Similarly, in a study on a glacier in Switzerland (Proctor, 1983), maximum RGR in relation to thallus size of $R$. geographicum appeared to be described by a similar curve to that of $B$. canescens initially exponential and rising asymptotically to a constant RGR. Proctor's data unfortunately did not include any thalli more than $36 \mathrm{~mm}$ in diameter, and growth rates in thalli over $10 \mathrm{~mm}$ were assumed to be linear with the growth curve extrapolated up to $60 \mathrm{~mm}$ without further measurement. Hence, although there is good evidence that placodioid species may grow similarly to foliose species (Hill 1981; Benedict 2008), this may not be the case for the areolate species Rhizocarpon.

In subsequent studies (reviewed by Bradwell and Armstrong 2007), variation in RGR between individual thalli was often too great to establish the shape of the growth curve with any certainty and, therefore, the data are not adequate to test the hypothesis that crustose and foliose lichens grow similarly. For example, Hooker (1980a) was unable to demonstrate any significant effect of thallus size on RGR in south Orkney and similarly, the study of Rogerson et al. (1994) on seven thalli in northern Labrador shed little light on the relationship between growth and size. Similar equivocal conclusions were reported by Matthews (1994), Winchester and Chaujar (2002), Sancho and Pintado (2004), and Armstrong (2005a). 
One of the first studies to question whether crustose lichens grew differently to foliose species was that of Brodo (1965) who examined corticolous communities in Long Island, New York. Brodo found a slight decline in the growth of crustose thalli greater than $40 \mathrm{~mm}$ in diameter compared with those $10-30 \mathrm{~mm}$ in diameter. Such a decline in the RGR of larger thalli was also suggested by studies of the growth curve of $R$. geographicum in north Wales (Armstrong 1983) (Fig. 4). Three phases of growth were identified: 1) an initial phase in which RGR increased to a maximum, 2) a short phase in thalli $30-40 \mathrm{~mm}$ in diameter in which RGR was maximal, and 3) a declining phase in which RGR fell in thalli $>50 \mathrm{~mm}$ in diameter. Haworth et al. (1986) also found evidence, although poorly defined, for an inverse relationship between thallus growth and size in Alaska. Further evidence for a declining phase in growth in larger thalli comes from a recent study of 134 thalli of four crustose lichen species growing at a single site in north Wales (Armstrong 2005b) and a study of $R$. geographicum in southern Iceland (Bradwell and Armstrong 2007). No evidence for an asymptotic growth rate-size curve was found in $R$. geographicum, Rhizocarpon reductans, Th. Fr. Lecidea tumida Massal., or Buellia aethalea (Ach.) Th. Fr. from north Wales or from R. geographicum in Iceland (Bradwell and Armstrong, 2007). Instead, RGR increased to a maximum and then declined in larger diameter thalli. In the absence of a suitable growth model for crustose lichens, second-order polynomial curves have been fitted to these data (Armstrong 2005b). However, further growth studies and especially those concentrating on smaller and larger-sized thalli are needed to define the shape of the size-growth curve more accurately. In this regard, the new results of Trenbirth and Matthews (this volume), who test several models for crustose lichen growth, are especially noteworthy.

That larger and presumably older crustose thalli may grow more slowly than younger individuals is suggested by many indirect lichenometric studies. Porter (1981) reviewed many of the differences in opinion regarding the lichen growth curve reported in the earliest studies. Prior to 1980, growth curves were variously reported as essentially linear (Andersen and Sollid 1971; Burrows and Orwin 1971), exponential (Mottershead and White 1972; Luckman 1977), exponential-linear (Benedict 1967; Denton and Karlén 1973), or 'irregular’ (Curry 1969). 
Studies since 1980 have provided some evidence of a declining phase of growth. Hence, Birkeland (1981) compared lichenometric and soil data from the Mount Cook region of New Zealand and found that the growth rate of $R$. geographicum decreased with time and did not maintain a linear relationship in this humid mountainous area. Bull and Brandon (1998) studied the growth of Rhizocarpon subgenus Rhizocarpon in the southern Alps of New Zealand and found that non-linear growth equations best fitted the growth curve. Colonization by the lichen was followed by a rapid exponential phase of growth for the first 20 years followed by a phase of slower more linear growth. The closest type of growth curve of $R$. geographicum, provided by indirect lichenometry, to that of direct measurement has been reported by O’Neal and Schoenenberger (2003). They revisited surfaces in the Cascades originally measured by Porter (1981) and found that the growth curve was curvilinear suggesting phases of increasing, constant, and decreasing RGR. These lichenometric findings and the inferred shape of the growth curve strikingly echo the conclusions of Armstrong (2005b) and Bradwell and Armstrong (2007), but for a further discussion of this issue see Trenbirth and Matthews (in press, this volume).

\section{Factors determining the growth rate-size curve}

In constructing a model to explain the growth of foliose species, Aplin and Hill (1979) speculated that crustose species such as $R$. geographicum might have a different type of growth rate-size curve. In such species, the hypothallus is the pioneering part of the organism, is non-photosynthetic, and is presumably being supplied with carbon compounds by the areolae. Hypothallus tissue contains the same lichen substances as the main part of the thallus (Fahselt 1976; Armstrong and Smith 1987) and hence, translocation of materials is likely to have taken place from areolae to hypothallus.

An important concept that may determine the growth of younger thalli is the ratio of algal to fungal mass (Clayden et al. 2004). Hence, Rhizocarpon lecanorinum may have a shorter life span than $R$. geographicum and may achieve maximum growth more rapidly because of its higher algal/fungal mass ratio. By contrast, in older thalli growth of the hypothallus may be determined by the rate at which materials are translocated from the areolae. Armstrong and Smith (1987) completely removed the 
central areolae from six thalli of $R$. geographicum and found no measurable radial growth of the hypothallus over 18 months. Removal of the areolae to within 1 and 2 mm of the hypothallus also reduced growth but in proportion to the width of the areolae present. These results suggest that it is the areolae that supply the hypothallus with materials for growth. Lange (1990) in studies carried out in the Negev desert using Caloplaca aurantia (Pers.) Hellb. (a species without a conspicuous marginal hypothallus) also found evidence for carbon translocation. Different portions of the thalli were removed and a marginal annulus of $12 \mathrm{~mm}$ was found to be sufficient to maintain the RGR of the perimeter; $6 \mathrm{~mm}$ not being sufficient. In addition, the concentration of the algal carbohydrate ribitol, and the fungal carbohydrates arabitol, and mannitol was measured in the marginal hypothallus and central areolae of $R$. geographicum on four occasions during a year (Armstrong and Smith 1987). The levels of the three carbohydrates were present at much higher concentration in the areolae than in the hypothallus which suggests that restriction of transport from areolae to hypothallus as hyphae age might be one explanation for the decreasing growth of larger $R$. geographicum thalli. Studies of C-14/C profiles across thalli of $R$. geographicum using mass spectroscopy, however, have provided little information to explain the growth curve (Bench et al. 2001). The profile across thalli was flat and with little spread. Hence, carbon cycling appeared to be associated largely with replacement and fusion of the central areolae rather than being important in determining growth at the margin.

An elegant hypothesis to explain the growth curves of different morphological types of lichen was proposed by Benedict (1985) who suggested that variations in the shapes of growth curves were dependent on the width of the peripheral growth zone, i.e., the area of thallus at the margin that supplies carbon for growth. Hence, if the peripheral growth zone is narrow, as in many foliose species, there is an early linear phase that truncates the sigmoidal growth curve and the result is essentially the asymptotic type of curve seen in many foliose species (Aplin and Hill 1979) and the placodioid species B. canescens (Proctor 1977) and Lecanora novomexicana (Benedict 2008). Alternatively, if the peripheral growth zone is wide, as in many ‘true’ crustose species (Lange 1990), the linear phase occurs later, after a sigmoidal pattern is established. This hypothesis was tested later by removing thallus interiors to create curved wedges of tissue while RGR was measured at various points 
corresponding to different widths (Benedict 2008). The radial growth of the foliose Xanthoparmelia coloradoensis and the placodioid Lecanora novomexicana accelerated with increasing wedge width, becoming linear at 2.01 and $0.12 \mathrm{~mm} \mathrm{yr}^{-1}$ respectively. By contrast, the radial growth of Rhizocarpon superficiale accelerated to a maximum of $0.016 \mathrm{~mm} \mathrm{yr}^{-1}$ then slowed at greater wedge widths to define a more complete sigmoidal curve. The curve did not, however, become linear - refuting this part of the hypothesis. These results suggest that less carbon is available for radial growth at greater wedge widths as more may be required to maintain older areolae or to develop reproductive structures.

A factor that could also contribute to a slowing of growth in crustose species is that many thalli form cracks when dry, which may affect the physiological integrity of the thallus (Hill 1981). Each areola is only in contact with the hypothallus or medulla at the level of the substratum. Hence, cracks could impede the lateral movement of carbohydrate from the algal layers to the growing tip and increasing cracking with age could explain the slow growth rates of larger thalli.

It is possible that changes affecting the hypothallus during the life of a lichen could be a factor determining the growth curve. In north Wales, RGR of a sample of thalli of $R$. geographicum was positively correlated with hypothallus width at the start of the experiment; a wider hypothallus indicating a faster growing individual (Armstrong and Bradwell 2001), a relationship also reported by Proctor (1983). The correlation may be a consequence of hypothallus width being negatively correlated with the time elapsed before measurable hypothallus growth was recorded, i.e., individuals with narrow hypothalli take considerably longer before there is measurable growth of the hypothallus. Growth may be delayed in thalli with narrow hypothalli because there may be alternating phases of areolae and hypothallus growth (Armstrong and Smith 1987) and a narrow hypothallus may simply indicate a phase of areolae growth. Nevertheless, little systematic change in hypothallus width occurs with thallus size in $R$. geographicum suggesting that it is unlikely to be a factor influencing the growth curve (Armstrong and Bradwell 2001). 


\section{The effect of environmental factors on growth}

There are few accurate data on the effects of individual environmental factors on the growth of crustose species. Instead, the effects of environmental factors are often inferred indirectly from studying growth in contrasting environments or by studying the marginal 'growth rings' of certain crustose species. For example, John (1989) studied the size of the largest thalli of three species of Rhizocarpon (subgroup Rhizocarpon) growing at a single site and found them to be significantly different. Clearly, each species was responding differently to local changes in microclimate. Beschel's detailed lichenometric studies in the 1950s and 1960s underlined the important role played by climate on lichen growth. He found the same species of Rhizocarpon to be growing considerably more slowly in Greenland when compared to growth rates in the Swiss Alps (Beschel 1958, 1961). Re-measurement of Beschel's lichens 12 years after his original study (Ten Brink 1973), confirmed that growth of Rhizocarpon geographicum was $>50 \%$ slower at those sites in Greenland furthest from the sea (6-7 mm/100yr vs. 17-18 mm/100yr). Since then, other lichenometric studies from the northern hemisphere have found similar trends. Innes (1983) found a general decrease in growth rate of Rhizocarpon section Rhizocarpon lichens from west to east in Scotland; Bradwell (2001a) found a growth rate gradient across Iceland; and Matthews (2005) found a similar phenomenon in southern Norway, probably reflecting reduced moisture availability associated with a diminishing maritime influence.

\section{Marginal zonation}

Certain species of the genera Pertusaria, Lecanora, and Ochrolechia have concentrically zoned margins (Fig. 5). In some species, there are alternating light and dark bands at the margin - the lighter bands probably representing rapid summer growth and the narrow dark zones representing growth in winter (Hale 1973). Each zone is therefore assumed to represent growth in one year and, in some thalli, growth can be traced back three to seven years. A detailed study of marginal zonation was carried out by Hooker (1980b) in Antarctica. He found that in Buellia russa (Hue.) Darb., zonation was present only in the non-lichenised hypothallus and that each concentric zone represented one year's growth. By contrast, B. coniops and Caloplaca 
cirrochrooides (Vainio) Zahbr. possessed 'pseudoannual rings' with new rings encompassing two growth seasons. In addition, the rings of Caloplaca were not as distinct as those of the other species and no new growth rings formed during two growing seasons. Hence, further research into these species is required before growth rings could be used as a reliable measure of growth variation in different habitats.

\section{Annual and seasonal variation}

The study of annual and seasonal growth variations has been a profitable method of studying the influence of climate on the growth of foliose species (Armstrong 1973; 1993) but there have been few corresponding studies of crustose lichens. Brodo (1965) studied annual variations in growth of the corticolous lichens Lecanora chlarotera Nyl. and L. caesiorubella Ach. and found significantly greater growth in 1959 - 1961 than in 1961 - 1962. The pattern of seasonal growth over three-month growth periods was studied in $R$. reductum and Lecidea tumida growing on rocks in north Wales (Armstrong 1973). Both showed maximum growth between May and July with relatively little growth between November and January and slow growth in August to October suggesting that a combination of higher rainfall and lower temperatures encouraged growth. In a further study (Armstrong 2006), RGR of a sample of $20 R$. geographicum thalli was measured in situ at three-month intervals over 51 months on a southeast-facing rock surface (Fig. 6). There were five periods of significant growth: July-September of 1993, 1994 and 1995, in January-March of 1996, and in April-June of 1997. In four of these periods, growth coincided with a mean temperature maximum (Tmax) over a three-month period exceeding $15^{\circ} \mathrm{C}$ and three of the maxima also coincided with greater than 450 sunshine hours. Two of the growth maxima coincided with three-month periods of total rainfall exceeding 300 $\mathrm{mm}$ and one with greater than 50 rain days in a three-month period. There were no significant linear correlations between RGR and the climatic variables measured. However, there were significant non-linear relationships between RGR and Tmax, the mean temperature minimum (Tmin), the total number of air and ground frosts, and the number of rain days in a growth period, the relationship with Tmax being the most significant. Hence, in north Wales, maximum growth of $R$. geographicum occurs in any season, although the period July-September appears to be the most favourable. Coxon and Kershaw (1983) studied changes in photosynthetic capacity in $R$. 
superficiale through the season. This species showed a broad response to temperature and a high resistance to heat stress, characteristic of species living in boundary-layer habitats, but there were no significant seasonal changes in photosynthetic capacity.

Aspect

A number of studies have reported the effects of aspect of the substratum on the growth of crustose lichens. In the Brooks Range, Alaska, for example, the growth rates of $R$. geographicum at sites with high to moderate light intensities were twice those at shaded locations (Haworth et al. 1986). Similarly, Bradwell (2001b) found that in Iceland, the largest thalli of $R$. geographicum were generally found on southfacing surfaces of boulders and it was concluded that this was a consequence of the longer thermal operating period and higher temperatures on these surfaces. In the Cascade Mountains, Washington State, the growth of R. geographicum on boulders was significantly greater on east-southeast and south-southeast facets compared with north facing facets (Armstrong 2005a). By contrast, the slope of the facet did not appear to influence growth. These studies might suggest that in northern hemisphere sites well-lit, south-facing surfaces are optimal for the growth of $R$ geographicum. In north Wales, however, a more complex relationship between growth and aspect was revealed (Armstrong 1974; 2002). R. geographicum is abundant on south-facing surfaces at these sites but exhibits significantly faster growth where the species occurs on northwest-facing surfaces (Armstrong 2002). The size-frequency distributions of the thalli also differed between these two habitats, with a higher percentage of thalli in the smallest size classes and a more restricted range of size on the northwest surfaces. The rate of mortality of the thalli also appeared to be greater on northwest surfaces. It was concluded that the RGR of $R$. geographicum did not predict its aspect distribution in north Wales and that the differing competitive environments on the two surfaces could explain the aspect distribution of this species rather than the direct effects of environmental factors.

\section{Effect of frost injury and snow}

Winter frost injury to lichens was studied in the Colorado Front Range by Benedict (1990a). Frost damage, which included spalling of the upper cortex and algal layers, 
was observed especially in foliose species. Crustose species such as Lecidea atrobrunnera and Rhizocarpon riparium Räsänen, by contrast, were least affected but some spalling was observed on the surface of the areolae.

A number of studies of growth have been carried out at high altitudes where snowfall is likely to be an important factor. Innes (1985) found that thalli were smaller than expected close to snow patches due to a reduced growing season and ground instability. At some sites, however, the effects of increasing moisture balanced the negative influence of snow. The effects of snow kill were elegantly demonstrated by Benedict (1990b). Under snow, thalli will respire but are unlikely to photosynthesise as light penetration is significantly reduced. Lines of lichen-covered rocks were installed in two semi-permanent snow patches in the Colorado Front Range. All thalli of $R$. geographicum died 5 to 8 years after transplanting when average duration of snow cover exceeded 40 to 43 weeks. By contrast, $R$. riparium thalli survived the duration of the study and were clearly more snow tolerant than $R$. geographicum. Benedict (1991) also studied the effect of snow on long-term lichen growth at high elevations by measuring the size of $R$. geographicum along a transect traversing snow free and snow accumulation areas. There were no systematic differences in maximum thallus diameter along the transect despite large differences in the duration of snow cover. These results suggested that that zoned lichen communities adjacent to snow patches were more likely to be attributable to episodic snow kill rather than to slow growth under seasonal snow cover.

\section{Implications for direct lichenometry}

Three aspects of crustose lichen growth have implications for lichenometry and especially the potential use of direct lichenometric curves. First, there is uncertainty regarding the early stages of development of members of the Rhizocarpon group and especially the possible lag times between colonization and the appearance of the first measurable thalli. Hence, studies of these early growth processes may enable more accurate estimates of the lag time. Second, there is uncertainty regarding the shape of the growth rate-size curves in the Rhizocarpon group. A major problem affecting most of the experimental growth data is the degree of variability between thalli of the same size which is often larger than the growth-size fluctuations of crustose lichens. 
Different models are currently being proposed for the shape of the growth-rate size curve in Rhizocarpon (Bradwell and Armstrong 2007; Trenbirth and Matthews, this volume) including models suggesting linear or increasing growth over time. It is possible that members of the Rhizocarpon group exhibit differently shaped growth curves at different sites or even at the same site in different years. If this hypothesis is correct, it would limit the application of directly measured lichen-growth curves across different regions. Third, crustose lichens exhibit seasonal patterns of growth (Armstrong 2006) and significant annual variations in growth rate. These variations may correlate with individual climatic factors (see Trenbirth and Matthews, this volume) and further knowledge of such relationships could enable growth curves in one region to be 'corrected' for use in others.

\section{Conclusions}

Many crustose lichens lack the vegetative propagules, such as isidia, soredia and thallus fragments, commonly produced by foliose species. Lichenization is therefore more likely to be involved in the reproduction of crustose lichens. Many crustose species comprise discrete granules (areolae) that contain the algal partner located on the surface of a non-lichenised hypothallus. Data suggest that primary areolae are formed from free-living algae on the substratum that by chance contact a short-lived hypothallus resulting from the germination of fungal spores. Experiments in the field suggest that the hypothallus can survive for a short time on its own, possibly by utilizing nutrients present in surface runoff (Armstrong and Smith 1987). By contrast, once the thallus is established, secondary areolae develop mainly from zoospores produced within the thallus itself (Armstrong and Smith, 1987).

Crustose lichens grow at substantially slower rates than most foliose species especially in higher latitude and higher altitude environments. Values of RGR as low as $0.006 \mathrm{~mm} \mathrm{yr}^{-1}$ have been recorded at the more extreme sites (Benedict 2008). Various factors may contribute to the slow growth of crustose compared with foliose species. First, foliose species are only loosely attached to the substratum and grow by hyphal elongation and consequently lobe extension. Crustose species, by contrast, have a more intimate association with the substratum and growth at the perimeter is often associated with the formation of new areolae on the surface of a fungal 
hypothallus. Second, translocation of carbohydrates may be more efficient within the lobes of an integrated foliose thallus than between the areolae and hypothallus of crustose lichens (Armstrong and Smith 1987). Supplying suitable levels of carbon to the margins of crustose lichens may be a particular problem, and although there is some evidence that the hypothallus can use exogenous sources of carbohydrate (Armstrong and Smith 1996), this may be possible only for brief periods. Third, crustose species can grow and survive in extreme environments and are particularly tolerant of low temperatures and frost injury (Benedict 1990b), and a low RGR may be an adaptation to these conditions.

Collective evidence suggests that the shape of the growth-rate size curve in crustose lichens may be different to that of foliose species; at least in those crustose species with marginal hypothalli. In foliose species the growth-rate curve is asymptotic, RGR increasing in small thalli and becoming relatively constant in larger thalli, and is well described by the Aplin and Hill (1979) model. By contrast, the growth-rate curve of crustose lichens may be 'parabolic', RGR increasing to a maximum and then declining in larger thalli (Armstrong 1983, 2005b; Bradwell and Armstrong 2007, Benedict 2008). The factors that determine the decline in RGR are unclear but it is possible that a gradual reduction in the translocation of carbohydrate to the marginal hypothallus with age is responsible (Benedict 2008). The development of a growth model for crustose lichens similar to that of Aplin and Hill (1979) would be an important advance and could also contribute to more accurate lichenometric dating. Note that other studies are proposing different models for the shape of the growth-rate curve in Rhizocarpon (Trenbirth and Matthews, this volume) and it is possible that the group exhibit differently shaped growth curves at different sites or even at the same site in different years.

There has been speculation that growth forms of the Rhizocarpon type may represent the most primitive type of crustose lichen. The importance of the marginal hypothallus to these species has been demonstrated by removing it experimentally (Armstrong and Smith 1987). In such experiments, a new hypothallus is developed within a relatively short time with regeneration occurring first by retreat of the marginal areolae, and second, by new hypothallus growth from the base of the areolae. Experiments also suggest that the margin of the areolae has a much greater 
potential ability to expand radially than the hypothallus (Armstrong and Smith 1987). It is possible that this growth form is an adaptation to ensure slow RGR and therefore, lower demands for nutrients from the environment. The consequence of allocating a smaller proportion of carbon for growth processes is that more becomes available for stress resistance. Hence, Rhizocarpon lichens and species with a similar growth form appear to be highly adaptable, enabling them to survive and grow in some of the most extreme environments on earth.

\section{Acknowledgements}

We are grateful to Jim Benedict and John Matthews for carefully reviewing the manuscript. TB publishes with the permission of the Executive Director, BGS (NERC).

Dr R.A. Armstrong, Vision Sciences, Aston University, Birmingham B4 7ET, UK, Email: R.A.Armstrong@aston.ac.uk

Dr Tom Bradwell, British Geological Survey, Murchison House, West Mains Road, Edinburgh, EH9 3LA, UK

Email:tbrad@bgs.ac.uk

\section{References}

Andersen, J.L. and Sollid J.L., 1971: Glacial chronology and glacial geomorphology in the margin zones of the glaciers, Midtdalsbreen and Nigardsbreen, south Norway. Norsk Geografisk Tidsskrift, 25: 1-28.

Aplin, P.S. and Hill, D.J., 1979: Growth analysis of circular lichen thalli. Journal of Theoretical Biology., 78: 347-363.

Armstrong, R.A., 1973: Seasonal growth and growth rate colony size relationships in six species of saxicolous lichens. New Phytologist, 72:1023-1030. 
Armstrong, R.A., 1974: The descriptive ecology of saxicolous lichens at a site in south Merionethshire, Wales. Journal of Ecology, 62: 33-45.

Armstrong, R.A., 1983: Growth curve of the lichen Rhizocarpon geographicum. New Phytologist, 94: 619-622.

Armstrong, R.A., 1993: Seasonal growth of foliose lichens in successive years in south Gwynedd, Wales. Environmental and Experimental Botany, 33: 225-232.

Armstrong, R.A., 2002: The effect of rock surface aspect on growth, size structure and competition in the lichen Rhizocarpon geographicum. Environmental and Experimental Botany, 48: 187-194.

Armstrong, R.A., 2005a: Radial growth of Rhizocarpon section Rhizocarpon lichen thalli over six years at Snoqualmie Pass in the Cascade Range, Washington State. Arctic, Antarctic and Alpine Research, 37: 411-415.

Armstrong, R.A., 2005b: Growth curves of four crustose lichens. Symbiosis, 38: 4557.

Armstrong, R.A., 2006: Seasonal growth of the crustose lichen Rhizocarpon geographicum (L.)DC. in south Gwynedd, Wales. Symbiosis, 41: 97-102.

Armstrong, R.A. and Smith, S.N., 1987: Development and growth of the lichen Rhizocarpon geographicum. Symbiosis, 3: 287-300.

Armstrong, R.A. and Smith, S.N., 1992: Lobe growth variation and the maintenance of symmetry in foliose lichen thalli. Symbiosis, 12: 145-158.

Armstrong, R.A. and Smith, S.N., 1996: Factors determining the growth curve of the foliose lichen Parmelia conspersa. New Phytologist, 134: 517-522.

Armstrong, R.A. and Smith, S.N., 1997: Factors associated with degeneration of the thallus centre in foliose lichens. Symbiosis, 22: 293-302. 
Armstrong, R.A. and Bradwell, T., 2001: Variation in hypothallus width and the growth of the lichen Rhizocarpon geographicum (L.) DC. Symbiosis, 30: 317-328.

Asta, J. and Letrouit-Galinou, M.A., 1995: Observations on the early growth of Rhizocarpon geographicum thalli. Herzogia, 11: 239-252.

Bench, G., Clark, B.M., Mangelson, N.F., St Clair, L.L., Rees, L.B., Grant, P.G, and Southen, J.R., 2001: Accurate lifespan estimates cannot be obtained from C-14 profiles in the crustose lichen Rhizocarpon geographicum (L.) DC. Lichenologist, 33: 539-542.

Benedict, J.B., 1967: Recent glacial history of an alpine area in the Colorado Front Range, USA. 1. Establishing a lichen-growth curve. Journal of Glaciology, 6: 817832.

Benedict, J.B., 1985: Arapaho Pass. Research Report 3, Center for Mountain Archeology, Ward, Colorado.

Benedict, J.B., 1990a: Experiments on lichen growth. I. Seasonal patterns and environmental controls. Arctic and Alpine Research, 22: 244-254.

Benedict, J.B., 1990b: Winter frost injury to lichens: Colorado Front Range. Bryologist, 93: 423-426.

Benedict, J.B., 1991: Experiments on lichen growth II. Effects of a seasonal snow cover. Arctic and Alpine Research, 23: 189-199.

Benedict, J.B., 2008: Experiments on lichen growth. III. The shape of the age-size curve. Arctic, Antarctic and Alpine Research, 40: 15-26.

Benedict, J.B., 2009: A review of lichenometric dating and its applications to archeology. American Antiquity, 74: 143-172. 
Beschel, R.E., 1958: Lichenometrical studies in West Greenland. Arctic 11: 254.

Beschel, R.E., 1961: Dating rock surfaces by lichen growth and its application to the glaciology and physiography (lichenometry). In Raasch G.O. (ed.), Geology of the Arctic, Toronto: University of Toronto Press, 1044-1062.

Birkeland, P., 1981: Soil data and the shape of the lichen growth curve for Mt Cook area. New Zealand Journal of Geology and geophysics, 24: 443-445.

Bradwell, T., 2001a: A new lichenometric dating curve for southeast Iceland. Geografiska Annaler, 83A: 91-101.

Bradwell, T., 2001b: Glacier fluctuations, lichenometry and climatic change in Iceland. PhD Thesis, University of Edinburgh, 365 pp.

Bradwell, T. and Armstrong, R.A., 2007: Growth rates of Rhizocarpon geographicum lichens: a review with new data from Iceland. Journal of Quaternary Science, 22: 311-320.

Brightman, F.H., 1959: Some factors influencing lichen growth in towns. Lichenologist, 1: 104-108

Brodo, I.M., 1965: Studies on growth rates of corticolous lichens on Long Island, New York. Bryologist, 68: 451-456.

Bull, W.R. and Brandon, M.T., 1998: Lichen dating of earthquake-generated regional rockfall events, southern Alps, New Zealand. GSA Bulletin, 110: 60-84.

Burrows, C.J. and Orwin, J., 1971: Studies of some glacial moraines in New Zealand. 1. The establishment of lichen-growth curves in the Mount Cook area. New Zealand Journal of Science, 14: 327-335.

Clayden, S.R., 1998: Thallus initiation and development in the lichen Rhizocarpon lecanorinum. New Phytologist, 139: 685-695. 
Clayden, S.R., Pentecost, A., Dawson, R.J.M., 2004: Growth of the lichen Rhizocarpon lecanorinum with comments on Aplin-Hill and lichenometric curves. Symbiosis, 37: 379-393.

Coxon, D.S.and Kershaw, K.A., 1983: The ecology of Rhizocarpon superficiale II. The seasonal response of net photosynthesis and respiration to temperature, moisture and light. Canadian Journal of Botany, 61: 3019-3030.

Curry, R.R., 1969: Holocene climatic and glacial history of the central Sierra Nevada, California. Geological Society of America (Special paper), 123: 1-47.

Denton, G.H. and Karlen, W., 1973: Lichenometry: its application to Holocene moraine studies in southern Alaska and Swedish Lapland. Arctic and Alpine Research, 5: 347-372.

Degelius, G., 1964: Biological studies of the epiphytic vegetation on twigs on Fraxinus excelsior. Acta Horti Gotoburgensis, 27: 11-55.

Fahselt, D., 1976: Prothallial lichen substances in two species of crustose lichens, Fuscidea cyathoides and Rhizocarpon geographicum. Canadian Journal of Botany, 54: 1742-1749.

Frey, E., 1959: Die Flechtenflora und-Vegetation des Nationalparks im Unterengardin. II. Teil. Ergeb Wiss Unters Schweiz Nationalparks, 6: 241-319.

Friedmann, E.I., 1982: Endolithic microorganisms in the Antarctic cold desert. Science, 215:1045-1053.

Grace, R.V. and Hayward, G.C., 1978: Establishment and monitoring of permanent lichen quadrats at Kawerna, New Zealand. Journal of the Auckland University Field Club, 24: 173-183. 
Hale, M.E., 1959: Studies on lichen growth rate and succession. Bulletin of the Torrey Botanical Club, 66: 126-129.

Hale, M.E., 1973: Growth. In: The Lichens. Ahmadjian V and Hale ME (eds). Academic Press, New York, pp 473-492.

Hale, M.E., 1967: The Biology of Lichens, First Ed., London, Edward Arnold, 176 pp.

Hausman, E.H., 1948: Measurements of the annual growth rate of two species of rock lichens. Bulletin of the Torrey Botanical Club, 75: 116-117.

Hawksworth, D.L. and Chater, A.O., 1979: Dynamism and equilibrium in a saxicolous lichen mosaic. Lichenologist, 11: 75-80.

Hawksworth, D.L. and Hill, D.J., 1984: The lichen-forming fungi. Blackie: Glasgow and London, 158 pp.

Haworth, L.A., Calkin, P.E. and Ellis, J.M., 1986: Direct measurement of lichen growth in the central Brooks Range, Alaska USA, and its application to lichenometric dating. Arctic and Alpine Research, 18: 289-296.

Hill, D.J., 1981: The growth of lichens with special reference to the modelling of circular thalli. Lichenologist, 13: 265-287.

Hooker, T.N., 1980a: Factors affecting the growth of Antarctic crustose lichens. British Antarctic Survey Bulletin, 50: 1-19.

Hooker, T.N., 1980b: Lobe growth and marginal zonation in crustose lichens. Lichenologist, 12: 313-323.

Innes, J.L., 1983: Development of lichenometric dating curves for highland Scotland. Transactions of the Royal Society of Edinburgh, 74: 23-32. 
Innes, J.L., 1985: Lichenometry. Progress in Physical Geography, 9: 187-254.

Innes, J.L., 1988: The use of lichens in dating. In Galun, M (ed.) Handbook of Lichenology. Boca Raton: CRC Press, pp 75-92.

John, E.A., 1989: Note on the sizes of the largest thalli of three species of Rhizocarpon (subgenus Rhizocarpon) at a rockslide in the Canadian Rocky Mountains. Arctic and Alpine Research, 21: 185-187.

Lange, O.L., 1990: Twenty-three years of growth measurements on the crustose lichen Caloplaca aurantia in the central Negev desert. Israel Journal of Botany, 39: 383-394.

Locke, W.W., III., Andrews, J.T. and Webber, P.J., 1979: A Manual for Lichenometry. British Geomorpholological Research Group, Technical Bulletin, 26: 1-47.

Luckman, B.H., 1977: Lichenometric dating of Holocene moraines at Mount Edith Cavell, Jasper, Alberta. Canadian Journal of Earth Sciences, 14: 1809-1822.

Matthews, J.A., 1994: Lichenometric dating: A review with particular reference to 'Little Ice Age' moraines in southern Norway. In Beck, C. (ed.), Dating in Surface Context, Albuquerque, New Mexico Press, pp. 185-212.

Matthews, J.A., 2005: Little Ice Age glacier variations in Jotunheimen, southern Norway: a study in regionally controlled dating of recessional moraines with implications for climate and lichen growth rates. The Holocene, 15: 1-19.

Matthews, J.A. and Owen, G. 2008: Endolithic lichens, rapid biological weathering and Schmidt hammer R-values on recently exposed rock surfaces: Storbreen glacier foreland, Jotunheimen, Norway. Geografiska Annaler, 90A: 287-297.

McCarthy, D.P., 1997: Habitat selection and ecology of Xanthoria elegans (Link) Th. Fr. in glacier forefields: Implications for lichenometry. Journal of Biogeography, 24: 363-373. 
McCarthy, D.P., 2003: Estimating lichenometric ages by direct and indirect measurement of radial growth: A case study of Rhizocarpon agg. At the Illecillewaet Glacier, British Columbia. Arctic Antarctic and Alpine Research, 35: 203-213.

Miller, G.H., 1973: Variations in lichen growth from direct measurements: preliminary curves for Alectoria minuscula from eastern Baffin Island, NWT Canada. Arctic and Alpine Research, 5: 333-337.

Miller, G.H. and Andrews, J.T., 1972: Quaternary history of northern Cumberland peninsula, east Baffin Island, North West Territory, Canada. VI. Preliminary lichen growth curve. Geological Society of America Bulletin, 83: 1133-1138.

Mottershead, D.M. and White, I.D., 1972: The lichenometric dating of glacier recession, Tunsbergdalsbre, Southern Norway. Geografiska Annaler, 54: 47-52.

Mukhtar, A., Garty, J., and Galun, M., 1994: Does the lichen alga Trebouxia occur free-living in nature: further immunological evidence. Symbiosis, 17: 247-253.

Nienburg, W., 1926: Anatomie der Flechten. In: Handbuch der Pflanzenanatomie. Vol. 6. Ed. K. Linstauer, Berlin, Borntraeger, pp 1-137.

O'Neal, M.A. and Schoenenberger, K.R., 2003: A Rhizocarpon geographicum growth curve for the Cascade Range of Washington and northern Oregon, USA. Quaternary Research, 60: 233-241.

Pentecost, A., 1981: Aspects of competition in saxicolous lichen communities. Lichenologist, 12: 135-144.

Porter, L., 1927: The rate of growth of lichens. Transactions of the British Mycological Society, 12: 149-152. 
Porter, S.C., 1981: Lichenometric studies in the Cascade range of Washington: establishment of Rhizocarpon geographicum growth curves at Mount Rainier. Arctic and Alpine Research, 13: 11-23.

Proctor, M.C.F., 1977: The growth curve of the crustose lichen Buellia canescens (Dicks) De Not. New Phytologist, 79: 659-663.

Proctor, M.C.F., 1983: Sizes and growth-rates of thalli of the lichen Rhizocarpon geographicum on the moraines of the Glacier de Valsorey, Valais, Switzerland. Lichenologist, 15: 249-261.

Rogerson, R.J., Evans, D.J.A., and McCoy, W.D., 1986: Five-year growth of rock lichens in a low-arctic mountain environment, Northern Labrador. Géographie physique et Quaternaire, XL: 85-91.

Rydzak, J., 1956: A method of studying growth in lichens. Annals of the University Mariae Curie-Sklodowska, (Sect C), 16: 1-15.

Sancho, L.G. and Pintado, A., 2004: Evidence of high annual growth rate for lichens in the martime Antarctic. Polar Biology, 27: 312-319.

Sanders, W.B. and Rico, V.J., 1992: Lichenizing rhizomorphs and thallus development in the squalulose lichen Aspicilea crespiana Rico. (Lecanorales, Ascomycetales). Botanica Acta, 105: 449-456.

Seaward, M.R.D., 1976: Performance of Lecanora muralis in an urban environment. In: Progress and Problems in Lichenology, D.H. Brown, D. L. Hawksworth, R.H. Bailey (eds), London, Academic Press.

Slocum, R.D., Admadjian, V. and Hildreth, K.C., 1980: Zoosporogenesis in Trebouxia gelatinosa: untrastructure, potential for zoospore release and implications for the lichen association. Lichenologist, 12: 173-187. 
Smith, R.I.L., 1995: Colonization by lichens and the development of lichen-dominated communities in the maritime Antarctic. Lichenologist, 27: 473-483.

Sowter, F.A., 1950: The cryptogamic flora of Leicestershire and Rutland, Lichens. Leicester, Leicester Library and Philosophical Society.

Ten Brink, N.W., 1973: Lichen growth rates in West Greenland. Arctic and Alpine Research, 5: 323-331.

Topham, P.B., 1977: Colonisation, growth, succession and competition. In: Lichen Ecology, M.R.D.Seaward (Ed), London, Academic Press.

Trenbirth, H.E. and Matthews, J.A. 2010: Lichen growth rates on glacier forelands in southern Norway: preliminary results from a 25-year monitoring programme. Geografiska Annaler (in press).

Winchester, V. and Chaujar, R.K., 2002: Lichenometric dating of slope movements, Nant Ffrancon, North Wales. Geomorphology, 47: 61-74. 
Table 1. Annual radial growth rates (RGR) of crustose lichens obtained by direct measurement. (Abbreviations and symbols: $\mathrm{C}=$ Candelariella, $\mathrm{D}=$ Diploschistes, $\mathrm{R}$. $=$ Rhizocarpon, L. = Lecanora, Le. $=$ Lecidea, $\max =$ maximum,${ }^{+}=$unpublished data, * Corrected from diameter growth rates, ? = unclear whether diameter growth rate or RGR measured)

$\underline{\text { Species }} \quad \underline{\text { Site }} \quad \frac{\underline{\mathrm{RGR}}}{\left(\underline{\mathrm{mm} \mathrm{yr}}^{-1}\right)} \quad \underline{\text { Reference }}$

\begin{tabular}{|c|c|c|c|}
\hline Aspicilia calcarea & Leicester & 1.1 & Sowter (1950) \\
\hline Aspicilia candida & Canada & 0.9 & $\begin{array}{l}\text { McCarthy and Smith } \\
\text { (1995) }\end{array}$ \\
\hline Buellia aethalea & North Wales & $0.15-1.40$ & Armstrong (2005) \\
\hline Caloplaca aurantia & Negev desert & 0.37 & Lange (1990) \\
\hline Caloplaca aurantia & Leicester & 2.0 & Sowter (1950) \\
\hline C. vitellina & North Wales & $0.34-1.47$ & Armstrong RA ${ }^{+}$ \\
\hline 'Crustose lichens' & New Zealand & $0.86 ?$ & $\begin{array}{l}\text { Grace and Hayward } \\
\text { (1978) }\end{array}$ \\
\hline Degelia plumbea & Ireland & 2.8 & Pentecost $\mathrm{A}^{+}$ \\
\hline Diploicia canescens & - & $0.01-0.33$ & Hill (1981) \\
\hline Diploicia canescens & Devon & $0.02-2.30$ & Proctor (1977) \\
\hline D. scruposus & USA & 0.44 & Hale (1959) \\
\hline D. scruposus & Germany & 2.0 & Frey (1959) \\
\hline D. scruposus & West Greenland & $2.0-3.0$ & Beschel (1961) \\
\hline Graphis scripta & Poland & $0.35-1.57$ & Rydzak (1956) \\
\hline L. caesiorubella & Long Island, NY & 0.36 & Brodo (1965) \\
\hline L. gangalioides & Cardigan & $0.1-0.7$ & $\begin{array}{l}\text { Hawksworth and Chater } \\
\text { (1979) }\end{array}$ \\
\hline L. alphoplaca & Germany & $0.67-1.40$ & Frey (1959) \\
\hline L. chlarotera & Long Island, NY & 0.84 & Brodo (1965) \\
\hline L. muralis & - & $0.03-0.55$ & Hill (1959) \\
\hline L. muralis & Surrey & 1.1 & Brightman (1959) \\
\hline L. muralis & Leicester & 1.25 & Sowter (1950) \\
\hline L. muralis & Leeds & $2.84-6.05$ & Seaward (1976) \\
\hline
\end{tabular}




\begin{tabular}{|c|c|c|c|}
\hline L. gangaleoides & North Wales & $0.90-2.0$ & Armstrong $\mathrm{RA}^{+}$ \\
\hline Lecidea tumida & North Wales & $0.12-1.04$ & Armstrong (2005) \\
\hline Lecidea coarctata & USA & 1.4 & Hale (1959) \\
\hline Lecidella euphorea & Cork, Ireland & 0.9 & Porter (1927) \\
\hline Le. elaeochroma & S. Scandinavia1.25 & \multicolumn{2}{|c|}{ Degelius (1964) } \\
\hline Ochrolechia parella & Cardigan & $0.6-1.4$ & $\begin{array}{l}\text { Hawksworth and Chater } \\
\text { (1979) }\end{array}$ \\
\hline Ochrolechia parella & North Wales & $0.65-1.45$ & Armstrong $\mathrm{RA}^{+}$ \\
\hline Pertusaria coccodes & Poland & $0.48-0.77$ & Rydzak (1956) \\
\hline Pertusaria corallina & North Wales & $0.85-1.42$ & Armstrong $\mathrm{RA}^{+}$ \\
\hline R. geographicum & West Greenland & $0.05-0.1$ & Beschel (1961) \\
\hline R. geographicum & S. Orkney & 0.1 & Hooker (1980a) \\
\hline R. geographicum & WA state, USA & 0.1 & Armstrong (2005) \\
\hline R. geographicum & Alaska & $0-0.18^{*}$ & Haworth et al. (1986) \\
\hline R. geographicum & West Greenland & $0.1-0.2$ & Ten Brink (1973) \\
\hline R. geographicum & Maritime Antarctic & $0.25 *$ & $\begin{array}{l}\text { Sancho and Pintado } \\
\text { (2004) }\end{array}$ \\
\hline R. geographicum & Canada & $0.05-0.29 *$ & Rogerson et al. (1986) \\
\hline R. geographicum & South Iceland & $0.09-0.37^{*}$ & $\begin{array}{l}\text { Bradwell and Armstrong } \\
\text { (2007) }\end{array}$ \\
\hline R. geographicum & New Hampshire & $0.4 ?$ & Hausman (1948) \\
\hline R. geographicum & BC, Canada & $0.26-0.41$ & McCarthy (2003) \\
\hline R. geographicum & Scotland & $0.09-0.50$ & Topham (1976) \\
\hline R. geographicum & Switzerland & 0.5 (max) & Proctor (1983) \\
\hline R. geographicum & North Wales & $0.03-0.94$ & Armstrong (2005) \\
\hline $\begin{array}{l}R . \text { geographicum } \\
\text { ssp. prospectans }\end{array}$ & North Wales & $0.67-0.81^{*}$ & $\begin{array}{l}\text { Winchester and Chaujar } \\
\text { (2002) }\end{array}$ \\
\hline Rhizocarpon subg. & South Norway & $0.33 *$ & Matthews (1994) \\
\hline Rhizocarpon subg. & South Norway & $0.18-0.44^{*}$ & $\begin{array}{l}\text { Trenbirth and Matthews } \\
\text { (this volume) }\end{array}$ \\
\hline R. reductum & Cardigan & $0-0.2$ & $\begin{array}{l}\text { Hawksworth and } \\
\text { Chater (1979) }\end{array}$ \\
\hline R. reductum & North Wales & $0.31-2.00$ & Armstrong (2005) \\
\hline R. superficiale & Colorado & 0.006 & Benedict (2008) \\
\hline
\end{tabular}




\section{Figure captions}

Figure 1. A thallus of the lichen Rhizocarpon geographicum (L.) DC on a talus slope on the Snow Lake trail, Cascade Mountains, Washington State, USA. The marginal black non-lichenized hypothallus is clearly evident (Bar $=1 \mathrm{~cm}$; Image courtesy $\mathrm{Dr}$ KM Wade).

Figure 2. Structure of the thallus of the crustose lichen Rhizocarpon geographicum.

Figure3. Mechanisms by which new areolae could be formed on the marginal hypothallus in lichens of Rhizocarpon type: A) from algal cells originating in central areolae, B) from zoospores originating in central areolae, C) from zoospores originating from adjacent thalli, D) from free-living algal cells on substratum.

Figure 4. The relationship between radial growth rate (RGR) (mm $\left.1.5 \mathrm{yr}^{-1}\right)$ and thallus size (growth-rate/size curve) for thalli of Rhizocarpon geographicum growing on slate rock surfaces in south Gwynedd, Wales, UK. (Goodness of fit to a second-order polynomial Pearson’s ‘ $r$ ’ $=0.54, \mathrm{P}<0.05$ ) (data from Armstrong 2005b).

Figure 5. Lichen growth rings at the margin of a thallus of Ochrolechia parella growing at a maritime site in north Wales (Bar $=1 \mathrm{~cm}$, Image courtesy Dr KM Wade).

Figure 6. Mean radial growth of thalli of Rhizocarpon geographicum measured in 17 three-month periods from 1993 to 1997 in south Gwynedd, Wales, UK. Analysis of variance (two-way), Between thalli, $\mathrm{F}=0.03$ ( $\mathrm{P}>0.05$ ), Between growth periods, $\mathrm{F}=$ 3.86 ( $\mathrm{P}<0.001)$ (data from Armstrong, 2006). 


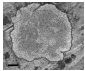




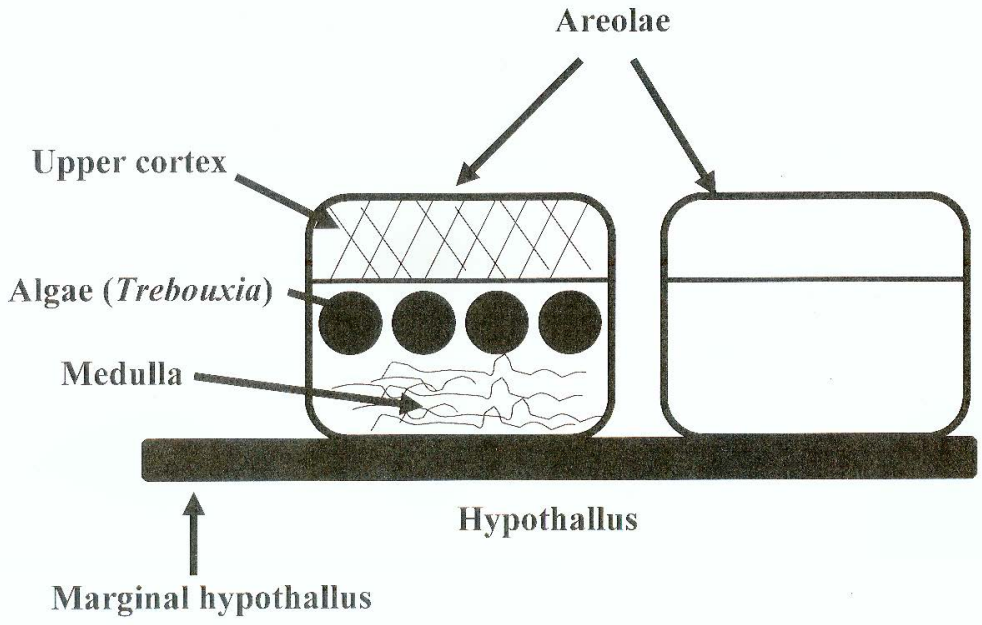




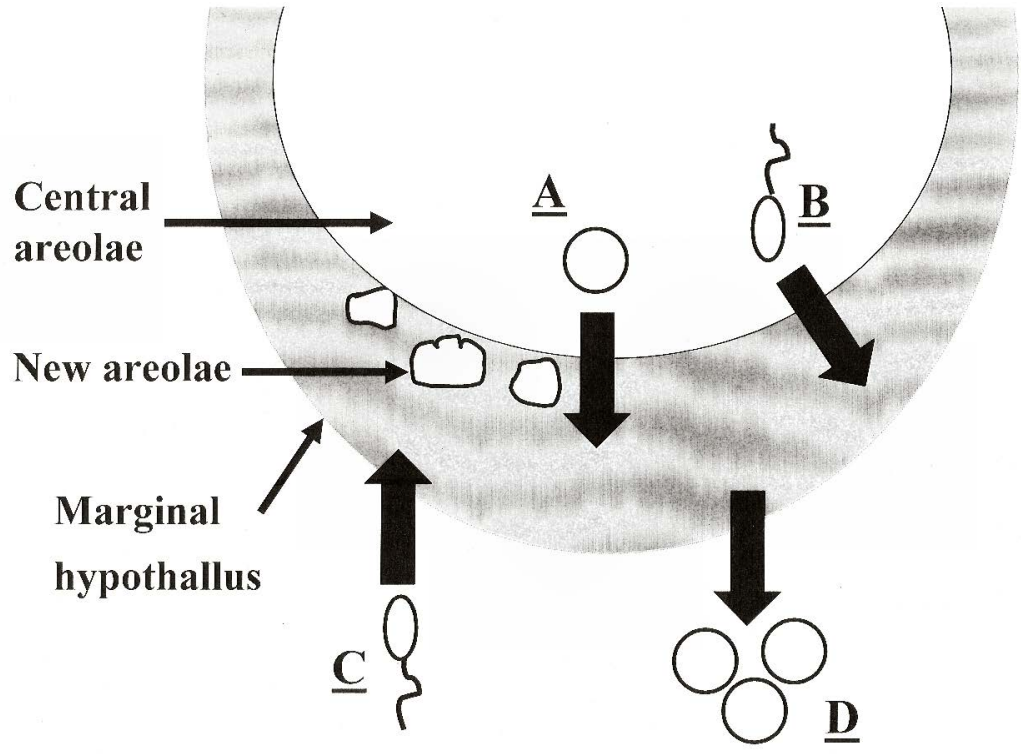




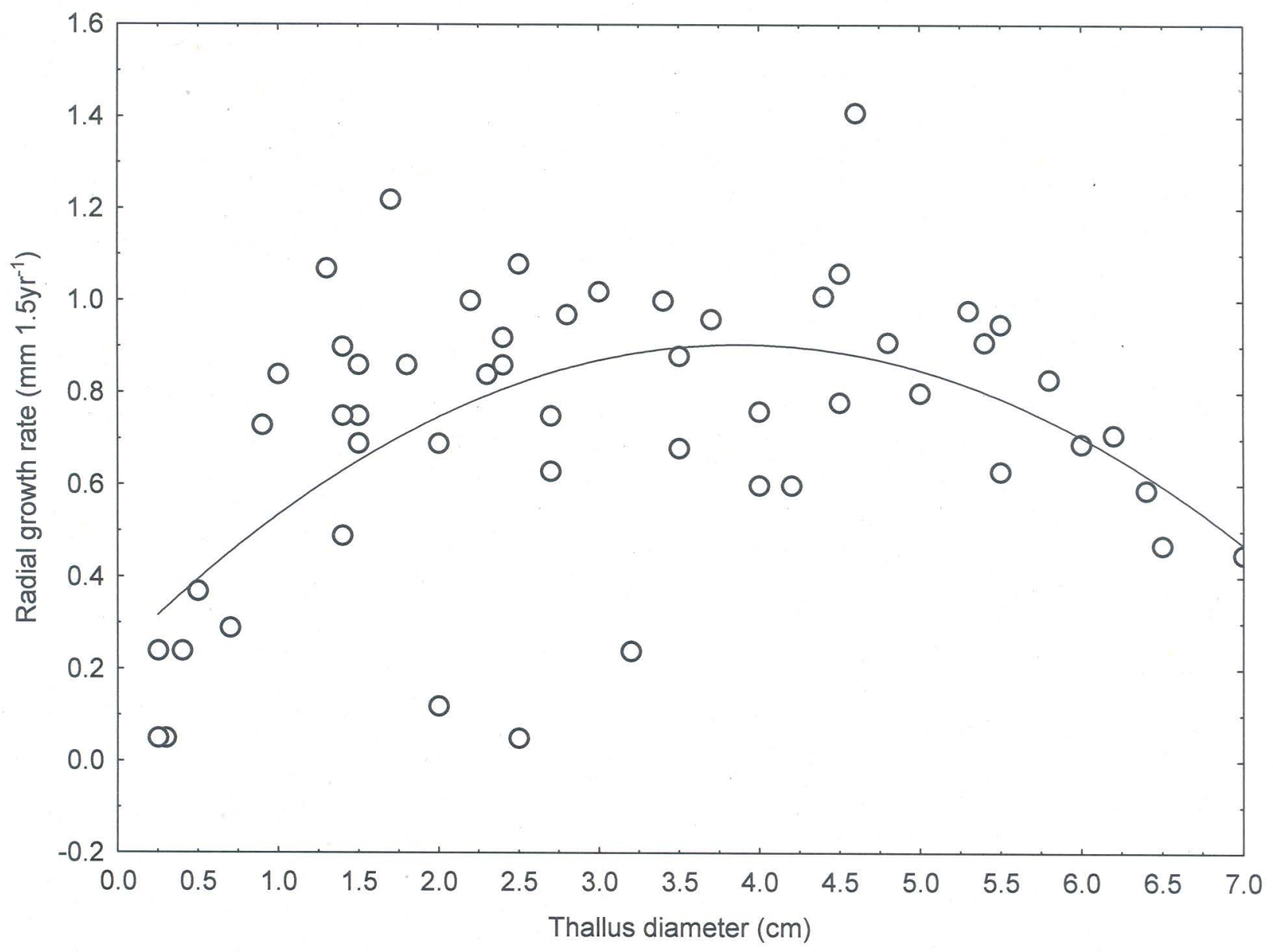




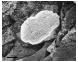




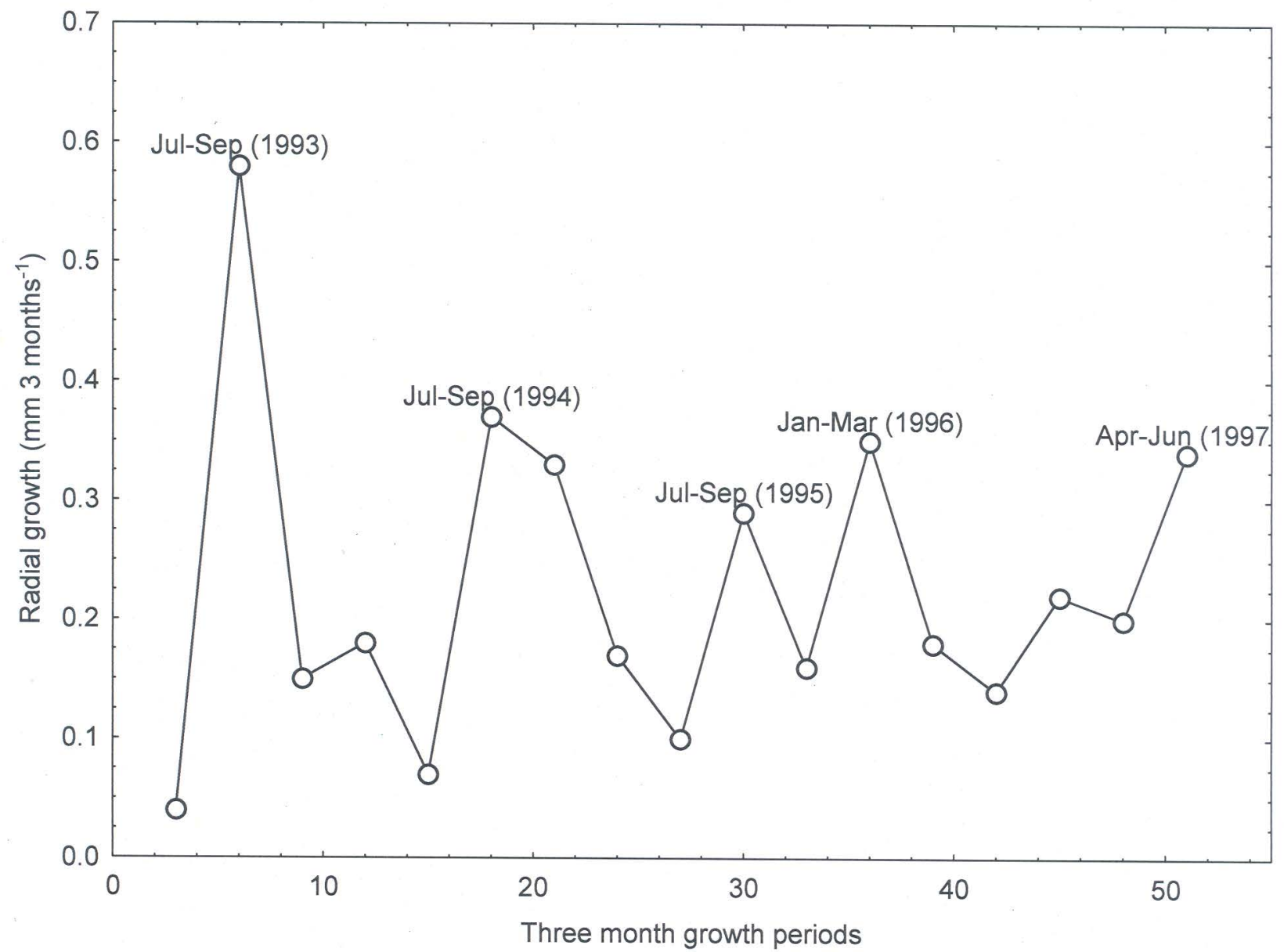

